\title{
Pineal Germ Cell Tumors: Review
}

\section{Germinatívne nádory pineálnej oblasti: prehl’ad}

\author{
Miskovska V. ${ }^{1}$, Usakova V. ${ }^{2}$, Vertakova-Krakovska B. ${ }^{2}$, Mrinakova B. ${ }^{2}$, Lehotska V. ${ }^{3}$, Chorvath M. ${ }^{4}$, Rychly B. ${ }^{5}$, \\ Steno J. ${ }^{6}$, Ondrus D. ${ }^{1}$ \\ ${ }^{1} 1^{\text {st }}$ Department of Oncology, Comenius University, Faculty of Medicine, St. Elisabeth Cancer Institute, Bratislava, Slovak Republic \\ ${ }^{2}$ Department of Medical Oncology, St. Elisabeth Cancer Institute, Bratislava, Slovak Republic \\ ${ }^{3} 2^{\text {nd }}$ Department of Radiodiagnostics, Comenius University, Faculty of Medicine, St. Elisabeth Cancer Institute, Bratislava, Slovak Republic \\ ${ }^{4}$ Department of Radiation Oncology, Slovak Medical University, St. Elisabeth Cancer Institute, Bratislava, Slovak Republic \\ ${ }^{5}$ Cytopathos, Bratislava, Slovak Republic \\ ${ }^{6}$ Department of Neurosurgery, Comenius University, Faculty of Medicine, University Hospital, Bratislava, Slovak Republic
}

\begin{abstract}
Summary
Background: Primary intracranial germ cell tumors represent a rare category of neoplasms, which occur in children and young adults. The WHO classification divides intracranial tumors into germinomas and non-germinomas. The most frequent locality of these tumors is pineal and suprasellar region. Clinical signs and symptoms depend on the localization of the tumour they most commonly include signs of increased intracranial pressure, Parinaud's syndrome, bitemporal hemianopsy and signs of endocrine deficiency. Gadolinium enhanced MRI scan of the brain is the imagining examination of choice in the diagnostic strategy of intracranial germ cell tumors. However, the imagining studies do not provide sufficient information about histological type; therefore, biopsy is necessary. The exception represents cases with characteristically increased levels of tumor markers (AFP and $\beta$-HCG) measured in the serum and cerebrospinal fluid. Case: A pineal germ cell tumor was observed in a 26-year-old male with presentation of an eye-sight disorder with focusing difficulty and photophobia, accompanied by intensive fatigue and sleepiness, nausea with occasional vomiting, intermittent headaches and Parinaud's syndrome. MRI examination of the brain showed tumor expansion in the pineal region and in the right part of the mesencephalon. Radical extirpation of the tumor in the pineal region was performed. The follow-up MRI scan of the brain revealed relapse of the disease. The patient underwent craniospinal radiation therapy with subsequent postoperative chemotherapy (regimen cisplatin and etoposide), three cycles in total. Currently, the patient is 30 months after finishing of oncological treatment in clinical remission of the disease. Conclusion: The treatment and prognosis of this neoplasm differ between particular categories. Germinomas have better survival rates than non-germinomas. A 5-year survival rate of germinoma patients after application of radiotherapy alone was $>90 \%$ of cases. The addition of chemotherapy lead to a decrease of the dose and minimalization of the irradiated area, with achievement of fewer side effects without a decrease of the curability. Non-germinomas are less radiosensitive than germinomas, but after the application of the adjuvant chemotherapy, survival benefit was achieved. However, the optimal management of these tumors remains controversial.
\end{abstract}

The authors declare they have no potential conflicts of interest concerning drugs, products, or services used in the study.

Autoři deklarují, že $v$ souvislosti s predmětem studie nemají žádné komerční zájmy.

The Editorial Board declares that the manuscript met the ICMJE "uniform requirements" for biomedical papers.

Redakční rada potvrzuje, že rukopis práce splnil ICMJE kritéria pro publikace zasílané do biomedicínských časopisů.

$\equiv$

Miskovska Vera, MD, Ph.D.

$1^{\text {st }}$ Department of Oncology, Comenius University, Faculty of Medicine St. Elisabeth Cancer Institute Heydukova 10

81250 Bratislava

Slovak Republic

e-mail: vieramiskovska@yahoo.fr

Submitted/Obdrženo: 25.11.2012

Accepted/Přrijato: 2. 12. 2012

Key words

pinealoma - germinoma - brain neoplasms - diagnosis - treatment 


\section{Súhrn}

Úvod: Primárne intrakraniálne germinatívne tumory predstavujú zriedkavú skupinu nádorov, ktoré sa vyskytujú v detstve a u mladých dospelých. WHO klasifikácia delí intrakraniálne tumory na germinómy a negerminómy. Najčastejšia lokalita týchto nádorov je pineálna a supraselárna oblast'. Klinické príznaky a symptómy závisia od lokalizácie tumoru, najčastejšie sú to príznaky v dôsledku zvýšeného intrakraniálnho tlaku, Parinaudov syndróm, bitemporálna hemianopsia, príznaky z endokrinného deficitu. Zobrazovacím vyšetrením vol'by pri diagnostike intrakraniálnych germinatívnych tumorov je MRI vyšetrenie mozgu s použitím kontrastnej látky gadolinium. Zobrazovacie vyšetrenia však neposkytnú dostatočnú informáciu o type nádoru, $\mathrm{k}$ tomu je potrebná bioptizácia. Výnimkou sú prípady s charakteristicky zvýšenými hladinami nádorových markerov (AFP a $\beta$-hCG) stanovenými v sére a cerebrospinálnom moku. Klinický prípad: U 26-ročného pacienta so zhoršeným zrakom s poruchou zaostrit’ a svetloplachostou, výraznou únavou a ospalostou, nevolnostou, občasným zvracaním, s intermitentnými bolestami hlavy a klinicky prítomným Parinaudovým syndróm sa zistil germinatívny nádor pineálnej oblasti. Zrealizované MR vyšetrenie mozgu ukázalo tumoróznu expanziu v pineálnej oblasti a v pravej časti mezencefala. Bola vykonaná radikálna exstirpácia tumoru v pineálnej oblasti. Pri kontrolnom MR vyšetrení mozgu sa zistila recidíva ochorenia. Pacient absolvoval kraniospinálne ožiarenie s následnou pooperačnou chemoterapiou (schéma cisplatina a etoposid), celkovo tri cykly. V súčasnej dobe je pacient 30 mesiacov po ukončení úspešnej onkologickej liečby v klinickej remisii ochorenia. Záver: Liečba a prognóza tohto nádorového ochorenia je rozdielna v jednotlivých skupinách. Germinómy majú lepšie preživanie než negerminómy. 5-ročné prežívanie germinómov po aplikácii samotnej rádioterapie bolo $>90 \%$. Pridanie chemoterapie viedlo k zníženiu dávky a zmenšeniu ožarovanej oblasti, s dosiahnutím menších nežiadúcich účinkov a bez zniženia kurability. Negerminómy sú menej rádiosenzitívne než germinómy, ale použitím adjuvantnej chemoterapie sa dosiahlo zlepšenie prežívania. Nad’alej však menežment týchto nádorov ostáva kontroverzný.

\section{Klúčové slová}

pinealóm - germinóm - mozgové nádory - diagnóza - liečba

\section{Introduction}

Primary intracranial germ cell tumours represent a rare category of neoplasms, which predominantly occur in childhood and young adult age. The incidence of these tumours in children with brain malignancies is higher in the Far East (Japan 10.3\%, Korea 11.2\%, Taiwan $14 \%)$ than in western countries (Canada $3.3 \%$, France $3.5 \%$, USA 4.1\%) [1-6]. The intracranial germ cell tumours share histologicalgenetic and treatment similarities with extracranial germ cell tumours $[7,8]$
The aim of this paper is to present our own experience with treatment of a patient with germ cell tumour of the pineal region.

\section{Case report}

26-year old man with 2-3 months history of diplopia, mydriasis and headache in frontal and occipital area was examined by regional neurologist, who stated the diagnosis of anincomplete lesion of the oculomotor nerve bilaterally, as a consequence of post-vaccination mesencephalitis after tetanus and diphtheria vaccination. Temporarily symptom improvement was achieved after the treatment. Three months later worsening of the clinical status occurred, moreover this time the eyesight disorder with focusing difficulty and photophobiawas accompanied by intensive fatigue and sleepiness, nausea with occasional vomitus and intermittent headache. Parinaud's syndrome was determined clinically. The patient was transported to the specialized higher-level medical facility, based on the CT scan findings of the tumour in the pi-

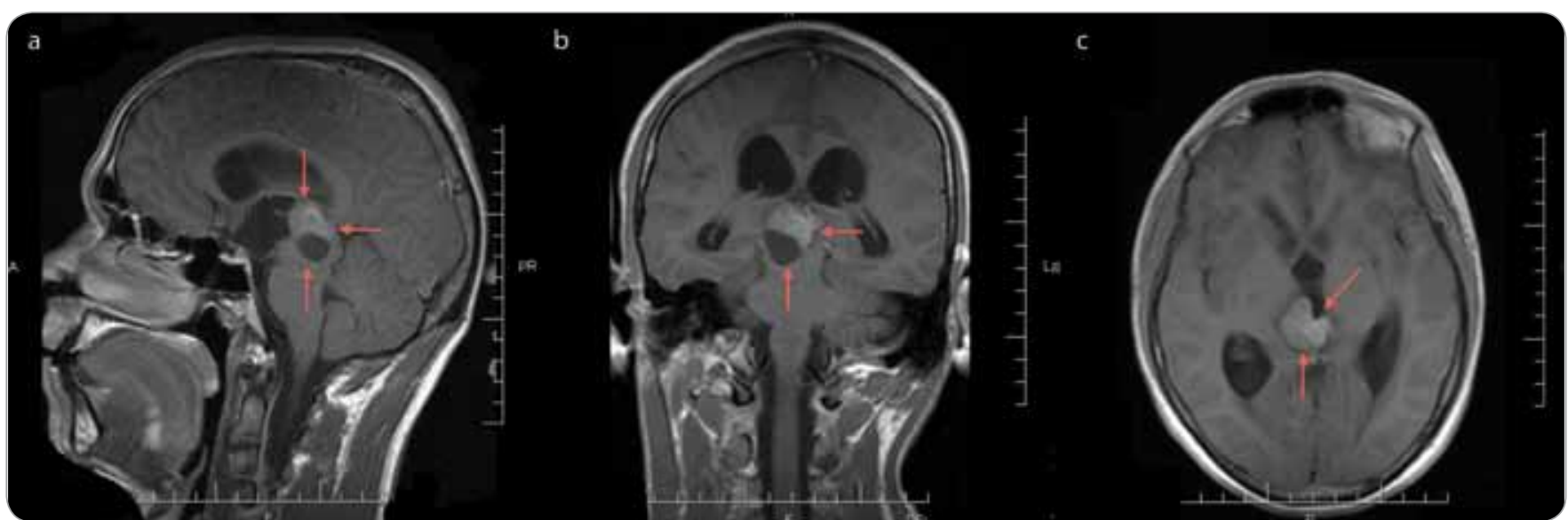

Fig. 1a. MRI T1-weighted postcontrast views - tumorous expansion of solid-cystic nature in the pineal region and in the right mesencephalon (arrows), penetrating the dorsal part of the $3^{\text {rd }}$ ventricle with compressed aqueduct of Silvius and 3-ventricular hydrocephalus - sagital view.

Fig. 1b. Coronal view.

Fig. 1c. Transversal view. 
neal region along with he three ventricular hydrocephalus, with the intention of surgical treatment.

An urgently performed MRI examination of the brain showed tumour expansion in the pineal region and in the right part of the mesencephalon, which had solid-cystic character with invasion into dorsal part of the thirdventricle and the compression of aqueduct of Sylvius, accompaniedby the obstructive hydrocephalus. The solid compound of the tumour was localized more closely to mid-line, $23 \times 20 \mathrm{~mm}$, the cystic compound of the tumour was localized right with caudal orientation, $17 \times 12 \mathrm{~mm}$. Poorly discoverable calcifications in the mid-line area on the margin of the tumour, $22 \times 25 \mathrm{~mm}$ (Fig. $1 \mathrm{a}-\mathrm{c}$ ) were also presented on the MRI scans.

The ventriculoperitoneal (V-P) drainage of the obstructive hydrocephalus was performed on the second day after MRI examination. Two days later, the radical extirpation of the tumour in pineal region was performed via infratentorial approach with histological findings of germinoma (tumour with solid, alveolar growth, with cells characterized by a more apparent and voluminous cytoplasm and vesicular nuclei, lymphoid stroma is also evident (HE 200X), immunohistochemistry is positive for PLAP (200x) (Fig. 2, 3).

The follow-up MRI scan of the brain, performed three months later, revealed a relapse of the disease in margins of the resection's cavity after extirpation of the germinoma in pineal region, with continuation into the thalamus on the right side and to upper mesencephalon with incipient infiltration of leptomeninges on the dorsal part of the nodus, the vertebral canal remained without signs of metastatic infiltration (Fig. $4 \mathrm{a}-\mathrm{c}$ ).

The patient underwent craniospinal radiation therapy in total dose (TD) for brain $55.0 \mathrm{~Gy}$ and for spine $27.0 \mathrm{~Gy}$ with subsequent postoperative chemotherapy (scheme cisplatin and etoposide), overall three cycles.

Currently the patient is 30 months after accomplishment of oncological treatment in clinical remission of the disease, according to repeated follow-up MRI scans (Fig. 5 a-c). From aneurolo-

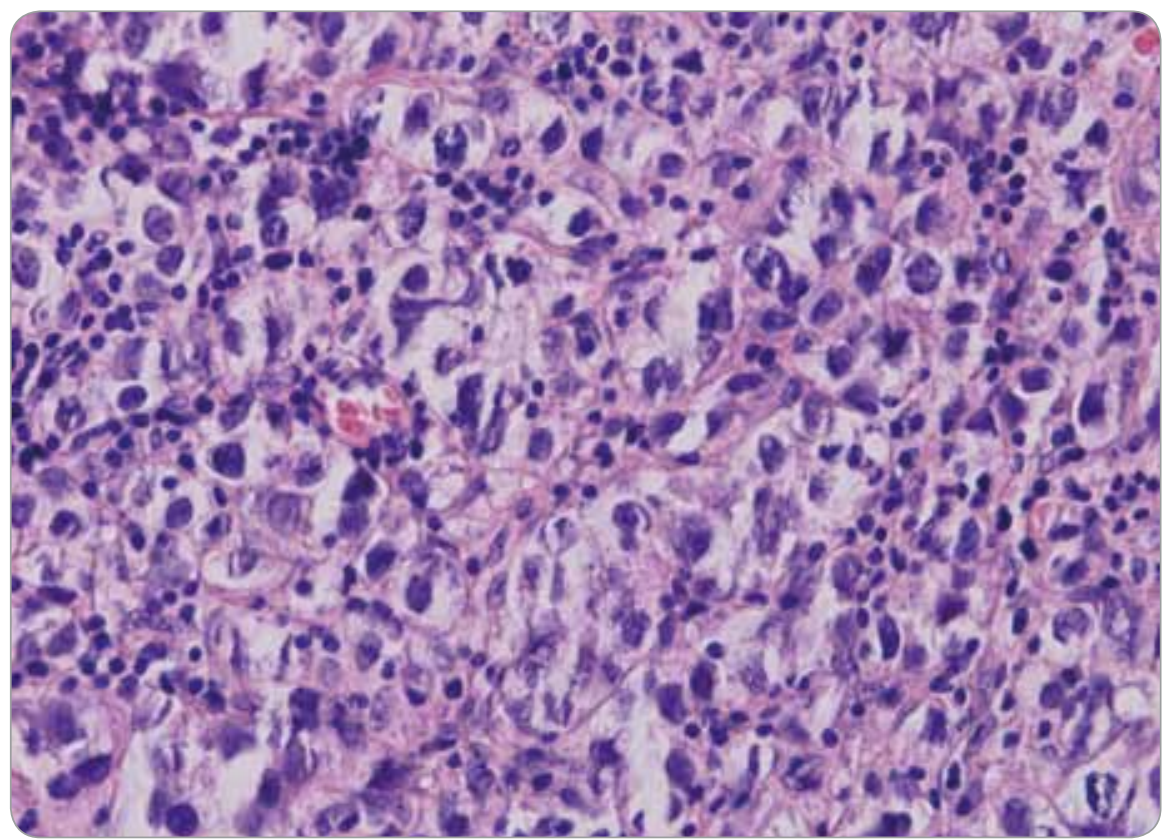

Fig. 2. Solid proliferation of neoplastic cells with voluminous clear cytoplasm and vesicular nuclei in the reactive lymphoid stroma, HE 400x.

gical point of view, the patient has no signs of Parinaud's syndrome.

\section{Discussion}

The WHO classification divides intracranial tumours into germinomas and non-germinomas, which include choriocarcinoma, yolk sac tumour, em- bryonal carcinoma, teratoma (mature, immature and teratoma with malignant differentiation) and mixed germcell tumours [9]. Germinomas represent $50-70 \%$, while non-germinomas the remaining third [10].

The most frequent locality of these tumours is pineal and neurohypophy-

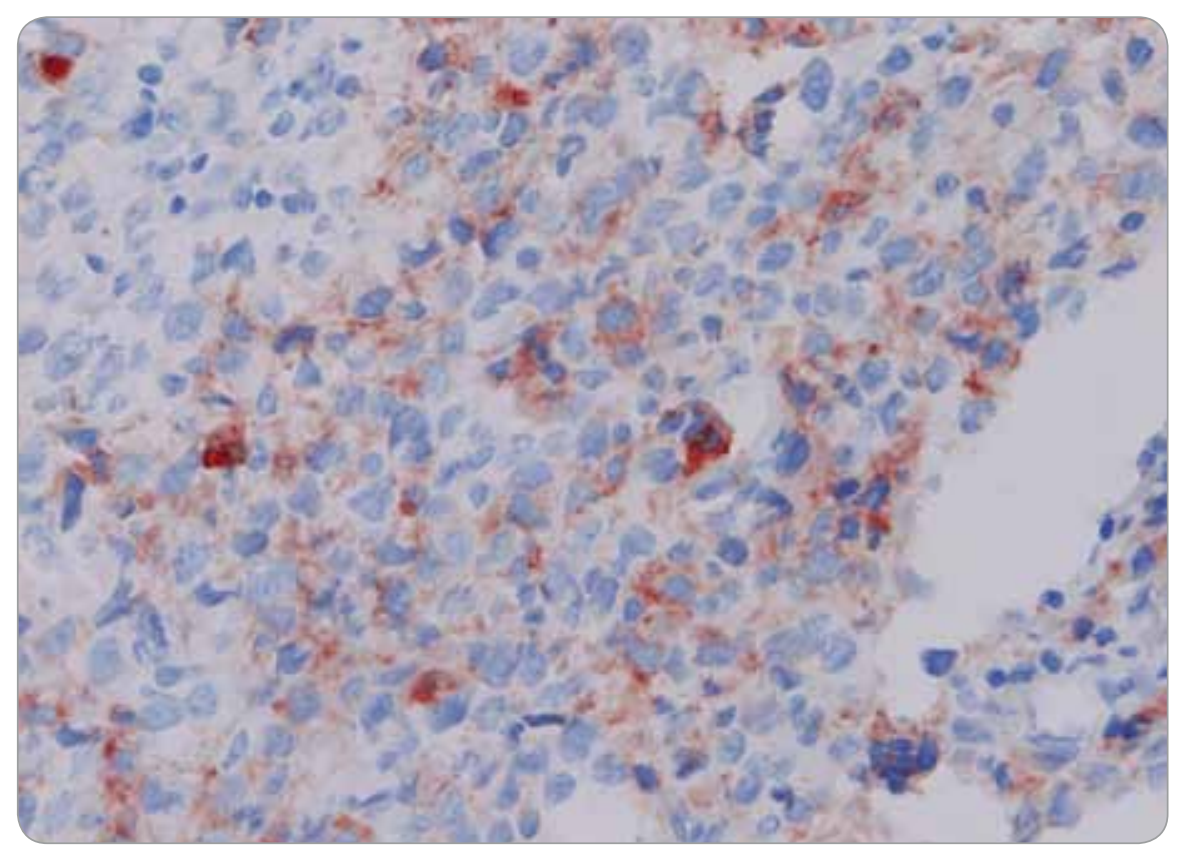

Fig. 3. Immunohistochemically depicted positivity of the neoplastic cells for PLAP (Placental Alkaline Phosphatase), 400x. 


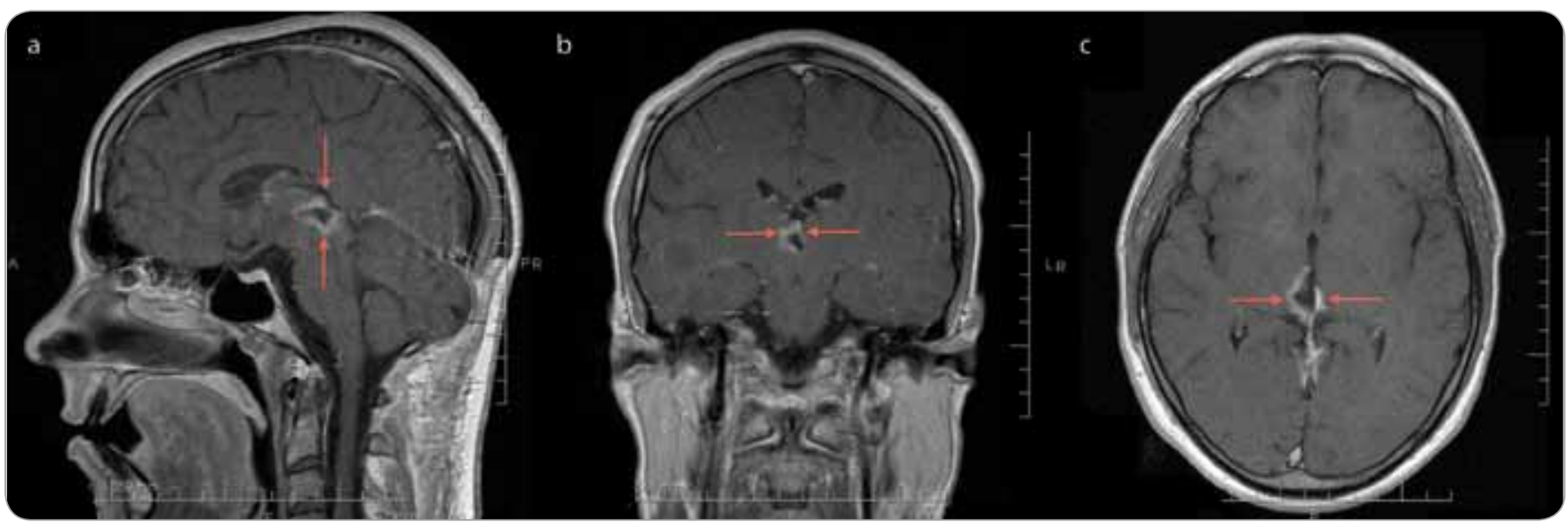

Fig. 4a. MRI T1-weighted postcontrast views - recurrent disease in the edge of surgical resection cavity in pineal region with involvement of the right thalamus and of the upper mesencephalon (arrows) - sagital view.

Fig. 4b. Coronal view.

Fig. 4c. Transversal view.

seal (suprasellar) region, less commonly they occur in basal ganglia or other brain localities (e.g. thalamus) $[11,12]$.

The age distribution of afflicted patients is unimodal, centering with an abrupt surge in frequency in the early pubertal years; $68 \%$ of patients are diagnosed between 10 and 21 years of age [10]. In our case report the age of the patient was 26 at the time of the diagnosis, which means he was an adult.

Clinical signs and symptoms depend on the tumour's localization. Tumours in the pineal region usually compress and obstruct cerebral aqueduct, which leads to an increase of the intracranial pressure and consequently hydrocephalus. It is manifested by headache, nausea, vomitus and somnolence. Another possible presentation of the tumour in the pineal region is Parinaud's syndrome (paralysis of upgaze, paralysis of downward gaze is less frequent, similarly to convergence disorder and/or convergence-retraction nystagmus). Parinaud's syndrome, partial or complete, is present in half of the patients [13]. As a result of the compression of optic chiasm, tumours localized in suprasellar region usually present with bitemporal hemianopsia and decrease of the visus. Invasion of the tumour into adenohypophysis causes endocrine deficiency, such as the delay of puberty in children and sexual dysfunction in adults, as an outcome of gonadoliberin deprival. Moreover the growth retardation can occur in children. Many of the suprasellar tumours manifest by the dysfunction of neurohypophysis leading to diabetes insipidus $[12,14,15]$.

Germ cell tumours produce specific markers that are measurable in the serum and cerebrospinal fluid [16]. Increased values of AFP occur in yolk sac tumours, lower values are observed in mixed germ cell tumours and immature teratoma with syncytiotrophoblastic activity. However the pure germinoma can secrete relatively low levels of the $\beta$-hCG, highest values are typically associated with choriocarcinoma [17].

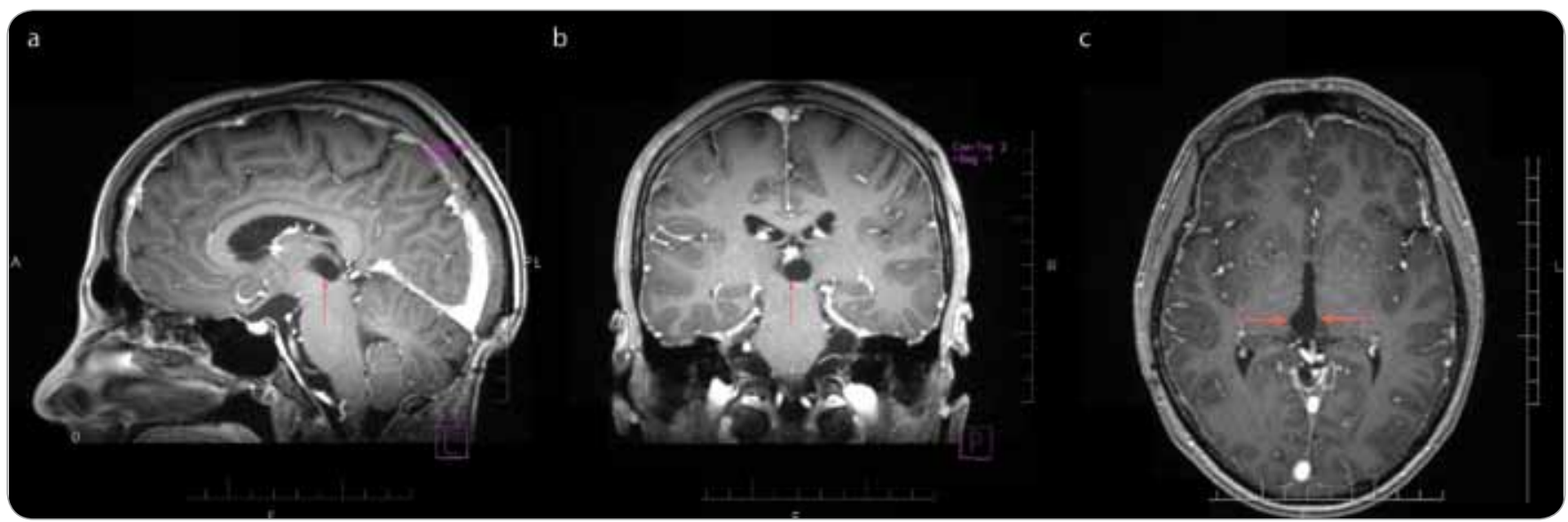

Fig. 5a. MRI T1-weighted postcontrast views - in the pineal region no detectable tumor, just a slight dilatation of the 3rd ventricle sagital view.

Fig. 5b. Coronal view.

Fig. 5c. Transversal view. 
The assessment of alkaline phosphatase is used more in immunohistochemistry, its positivity is diagnostically significant for germinomas $[18,19]$. Gadolinium enhanced MRI scan of the brain is the imagining examination of choice in the diagnostic strategy of intracranial germ cell tumours. In case of inaccessibility to a MRI, CT examination is also convenient $[20,21]$. The calcifications of the tumours in pineal region occur in as much as $70 \%$ of cases, however this finding is not common in pediatric patients, hence the X-ray of the skull may lead to diagnosis of the pineal tumour [22]. For the diagnosis of the potential leptomeningeal infiltration it is vital to perform a MRI of the spinal cord $[23,24]$.

The obstructive hydrocephalus is a clinical sign of many patients with tumours in the pinealregion, which usually requires the implantation of a ventriculoperitoneal shunt or endoscopic ventriculostomy of the third ventricule [25]. The imagining studies do not provide sufficient information about histological type, therefore the biopsy is necessary [26]. The exception represents cases with characteristically increased levels of tumour markers [27]. The importance of partial or complete resection of the germinoma was not defined and the role of a radical resection in non-germinoma is still unclear, although the complete resection of patients with mature teratoma has a curative effect [28-30]. In patients with non-germinoma, who didn't reach complete radiographic response after chemotherapy and who's tumour marker levels have been normalized, the "second-look surgery" should be considered. The histological finding may include necrosis or fibrosis, but the so-called growing teratoma syndrome may also be detected, in this case surgical treatment is the sole curative modality [31]. Likewise the "Second-look surgery" is advised for a better histological evaluation and confirmation of the presence of residual malignant elements, in a situation, when the normalized tumour marker levels are not reached.

Germinomas are radiosensitive tumours. 5-year survival after application of radiotherapy alone is more than $90 \%$ of cases. According to these excellent re- sults and also the side effects in children, such as influence on growth, cognitive functions and neuroendocrine development [32-34], various authors concentrated on lowering the doses with the intention of reducing side effects $[35,36]$. Several studies draw the conclusion that craniospinal radiotherapy is not essential in localized germinomas [37]. Combined chemotherapy regimens based on platinum showed high treatment efficacy in testicular germ cell tumours, consequently germ cell tumours in the CNS had also become candidates for chemotherapy. Fouladi et al [38] and Sawamara et al [39] achieved comparable results of survival with the use of platinum based chemotherapy and low doses of radiotherapy. Aomaya et al [40] applied three or four cycles of platinum based chemotherapy, depending on the resection extend, with sequential application of radiotherapy in the dose of $27.0 \mathrm{~Gy}$ towards affected area. The overall 5-year survival and disease free survival for pure germinoma was $100 \%$, resp. $86 \%$. In patients with germinoma with increased values of $\beta$-hCG the overall survival, resp. disease free survival was $100 \%$, resp. $44 \%$.

The non-germinomas are less radiosensitive than pure germinomas. The prognosis in patients treated with craniospinal radiotherapy alone is worse with 5 -year survival $30-50 \%$ and early relapse of the disease [14,41]. The addition of chemotherapy may improve the overall survival of patients with non-germinomas of the CNS [42-45]. Radiotherapy remains a vital accepted treatment strategy in the therapy of non-germinomas of the CNS. However, the necessity of craniospinal radiotherapy versus "focal or whole-ventricular radiotherapy" remains controversial, particularly in patients with localized disease [27].

\section{References}

1. Felix I, Becker LE. Intracranial germ cell tumors in children: an immunohistochemical and electron microscopic study. Pediatr Neurosurg 1990; 16(3): 156-162.

2. Baucher L, Rigau V, Mathieu-Daude H et al. Clinical epidemiology for childhood primary central nervous system tumors. J Neurooncol 2009; 92(1): 87-98.

3. CBTRUS, Central Brain Tumor Registry of the United States (2009) Statistical Report 2004-2005. Available a http://www.cbtrus.org.

4. Mori K, Kurisaka M. Brain tumors in childhood: statistical analysis of cases from the Brain Tumor Registry of Japan. Child's Nerv Syst 1986; 5(2): 233-237.
5. Cho KT, Wang KC, Kim SK et al. Pediatric brain tumors: statistics of SNUH, Korea (1959-2000). Childs Nerv Syst 2002: 18(1-2): 30-37.

6. Wong TT, Ho DM, Chang KP et al. Primary pediatric brain tumors: statistics of Taipei VGH, Taiwan (1975-2004). Cancer 2005; 104(10): 2156-2167.

7. Bentley AJ, Parkinson MC, Harding BN et al. A comparative morphological and immunohistochemical study of testicular seminomas and intracranial germinomas. Histopathology 1990; 17(5): 443-449.

8. Beeley JM, Daly JJ, Timperley WR et al. Ectopic pinealoma: an unusual clinical presentation and histochemical comparison with a seminoma of the testis. J Neurol Neurosurg Psychiatry 1973; 36(5): 864-873.

9. Louis DN, Ohgaki H, Wiestler OD et al. The 2007 WHO Classification of Tumours of the Central Nervous System. Acta Neuropathol 2007; 114(2): 97-109.

10. Jennings MT, Gelman R, Hochberg F. Intracranial germ-cell tumors: Natural history and pathogenesis. J Neurosurg 1985; 63(2): 155-167.

11. Masao M. Pineal Germ Cell Tumors. In: Kobayashi T, Lunsford LD (eds). Pineal Region Tumors. Diagnosis and Treatment Options. Prog Neurol Surgery. Basel Karger 2009; 23: 76-85

12. Vedrine L, Bauduceau O, Fayolle M et al. Combined chemotherapy and radiation therapy for intracranial germinomas. The Val-de-Grace hospital experience. Cancer Radiother 2005; 9(5): 335-340

13. Lapras C, Mottolese C, Jouvet A. Pineal region tumors. In: Choux M, Di Rocco C, Hockley A, Walker M (eds). Pediatric neurosurgery. London: Churchill Livingstone 1999: 549-560

14. Matsutani M, Sano K, Takakura K et al. Primary intracranial germ cell tumors: a clinical analysis of 153 histologically verified cases. J Neurosurg 1997; 86(3): 446-455.

15. Saeki N, Takami K, Murai H et al. Long-term outcome of endocrine function in patients with neurohypophyseal germinomas. Endocr J 2000; 47(1): 83-89.

16. Allen JC, Nisselbaum J, Epstein F et al. Alphafetoprotein and human chorionic gonadotropin determination in cerebrospinal fluid. An aid to the diagnosis and management of intracranial germ-cell tumors. J Neurosurg 1979; 51(3): 368-374

17. Inamura T, Nishio S, Ikezaki K et al. Human chorionic gonadotropin in CSF, not serum, predict outcome in germinoma. J Neurol Neurosurg Psychiatry 1999; 66(5): 654-657.

18. Shinoda J, Ymada H, Sakai $\mathrm{N}$ et al. Placental alkaline phosphatase as a tumor marker for primary intracranial germinoma. J Neurosurg 1988; 68(5): 710-720.

19. Kretschmar CS. Germ cell tumors of the brain in children: a review of current literature and new advances in therapy. Cancer Invest 1997; 15(2): 187-198.

20. Tien RD, Barkovich AJ, Edwards MS. MR imaging of pineal tumors. AJR Am J Roentgenol 1990; 155(1): 143-151. 21. Fujimaki T, Matsutani M, Funada $\mathrm{N}$ et al. CT and MRI features of intracranial germ cell tumors. J Neurooncol 1994; 19(3): 217-226.

22. Smirniotopoulos JG, Rushing EJ, Mena H. Pineal region masses: differential diagnosis. Radiographics 1992; 12(3): 577-596.

23. Sifat H, Haddadi K, el Ghazi E et al. Central nervous system germinoma: retrospective study of six cases. Cancer Radiother 2002; 6(5): 273-277.

24. Gauvrit JY, Soto Ares G, Hamon-Kerautret M et al. Imagerie des tumeurs de la région pinéale. Feuillets de Radiologie 1997; 37(4): 287-299.

25. Ray P, Jallo Gl, Kim RY et al. Endoscopic third ventriculostomy for tumor-related hydrocephalus in a pediatric population. Neurosurg Focus 2005; 19(6): E8.

26. Kang JK, Jeun SS, Hong YK et al. Experience with pineal region tumors. Childs Nerv Syst 1998; 14(1-2): 63-68 
27. Echevarría ME, Fangusaro J, Goldman S. Pediatric Central Nervous System Germ Cell Tumors: A Review. The Oncologist 2008; 13(6): 690-699.

28. Packer RJ, Cohen BH, Cooney K. Intracranial germ cell tumors. The Oncologist 2000; 5(4): 312-320.

29. Balmaceda C, Finlay J. Current advances in the diagnosis and management of intracranial germ cell tumors. Curr Neurol Neurosci Rep 2004; 4(3): 253-262.

30. Sawamura Y, de Tribolet N, Ishii N et al. Management of primary intracranial germinomas: Diagnostic surgery or radical resection? J Neurosurg 1997; 87(2): 262-266.

31. O'Callaghan AM, Katapodis O, Ellison DW et al. The growing teratoma syndrome in a nongerminomatous germ cell tumor of the pineal gland: A case report and review. Cancer 1997; 80(5): 942-947.

32. Sutton LN, Radcliffe J, Goldwein JW et al. Quality of life of adult survivors of germinomas treated with craniospinal irradiation. Neurosurg 1999; 45(6): 1292-1297.

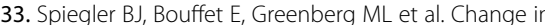
neurocognitive functioning after treatment with cranial radiation in childhood. J Clin Oncol 2004: 22(4): 706-713. 34. Benesh M, Lackner $H$, Schagerl $S$ et al. Tumor- and treatment-related side effects after multimodal therapy of childhood intracranial germ cell tumors. Acta Paediatr 2001; 90(3): 264-270.

35. Sawamura Y, Ikeda J, Shirato H et al. Germ cell tumours of the central nervous system: Treatment consideration based on 111 cases and their long-term clinical outcomes. Eur J Cancer 1998: 34(1): 104-110.

36. Shibamoto Y, Takahashi M, Abe M. Reduction of the radiation dose for intracranial germinoma: A prospective study. Br J Cancer 1994; 70(5): 984-989.

37. Rogers SJ, Mosleh-Shirazi MA, Saran FH. Radiotherapy of localised intracranial germinoma: Time to sever historical ties? Lancet Oncol 2005; 6(7): 509-519.

38. Fouladi M, Grant R, Baruchel S et al. Comparison of survival outcomes in patients with intracranial germinomas treated with radiation alone versus reduced-dose radiation and chemotherapy. Childs Nerv Syst 1998; 14(10): 596-601

39. Sawamura Y, Shirato H, Ikeda J et al. Induction chemotherapy followed by reduced-volume radiation therapy for newly diagnosed central nervous system germinoma. J Neurosurg 1998; 88(1): 66-72.

40. Aoyama H, Shirato H, Ikeda J et al. Induction chemotherapy followed by low-dose involved-field radiotherapy for intracranial germ cell tumors. J Clin Oncol 2002; 20(2): 857-865.

41. Hoffman HJ, Otsubo H, Hendrick EB et al. Intracranial germ-cell tumors in children. J Neurosurg 1991; 74(4): 545-551.

42. Robertson PL, DaRosso RC, Allen JC. Improved prognosis of intracranial non-germinoma germ cell tumors with multimodality therapy. J Neurooncol 1997; 32(1): 71-80.

43. Baranzelli MC, Patte C, Bouffet E. Carboplatin-based chemotherapy (CT) and focal radiation (RT) in primary cerebral germ cell tumors (GCT): A French Society of Pediatric Oncology (SFOP) experience. Proc Am Soc Clin Oncol 1999; 18: 140A.

44. Calaminus G, Bamberg M, Harms D et al. AFP/betaHCG secreting CNS germ cell tumors: Long-term outcome with respect to initial symptoms and primary tumor resection. Results of the cooperative trial MAKEI 89. Neuropediatrics 2005; 36(2): 71-77.

45. Calaminus $\mathrm{G}$, Bamberg $\mathrm{M}$, Jörgens $\mathrm{H}$ et al. Impact of surgery, chemotherapy and irradiation on long term outcome of intracranial malignant non-germinomatous germ cell tumors: Results of the German Cooperative Trial MAKEl 89. Klin Paediatr 2004; 216(3): 141-149. 